\title{
Bank efficiency in Malaysia: a use of malmquist meta-frontier analysis
}

\author{
Md. Abul Kalam Azad ${ }^{1}$ (D) Susila Munisamy ${ }^{1}$. \\ Abdul Kadar Muhammad Masum² ${ }^{2}$ \\ Paolo Saona $^{3}$ - Peter Wanke ${ }^{4}$
}

Received: 29 January 2016/Revised: 28 June 2016/ Accepted: 2 August 2016

(C) Eurasia Business and Economics Society 2016

\begin{abstract}
This paper uses a two-stage data envelopment analysis to examine bank efficiency in Malaysia. In the first stage, we use meta-frontier technology to address bank heterogeneity-bank nature (Islamic vs. conventional banks) and bank ownership (local vs. foreign banks). Using a data set of 43 Malaysian commercial banks, the application of meta-frontier enables us to compare the existence of inefficiency among Malaysian banks because of their business nature and ownership. In doing so, we empirically demonstrate that using different approaches (i.e., production, profitability, and intermediation) for calculating bank efficiency can give significant contradictory results in efficiency scores. In the second stage, we use Simar and Wilson's double bootstrap regression to estimate the determinants of efficiency in
\end{abstract}

Susila Munisamy

susila@um.edu.my

Md. Abul Kalam Azad

azadiiuc@gmail.com

Abdul Kadar Muhammad Masum

akmmasum@yahoo.com

Paolo Saona

psaonaho@slu.edu

Peter Wanke

peter@coppead.ufrj.br

1 Department of Applied Statistics, Faculty of Economics and Administration, University of Malaya, 50603 Kuala Lumpur, Malaysia

2 Department of Administrative Studies and Politics, Faculty of Economics and Administration, University of Malaya, 50603 Kuala Lumpur, Malaysia

3 Business and Economics Department, Saint Louis University, Avda. del Valle, 34, 28003 Madrid, Spain

4 COPPEAD Graduate Business School, Federal University of Rio de Janeiro, Rua Paschoal Lemme, 355, 21949-900 Rio De Janeiro, Brazil 
Malaysian banks. This helps to achieve valid inference even in the presence of unknown serial correlation in the meta-frontier efficiency scores. The results from double bootstrap regression confirm that bank ownership, bank nature and gross domestic product have significant influence on bank efficiency. This study reveals that Islamic banks have outperformed. The frontier results reveal that local Islamic banks have moved towards the group technology and foreign Islamic banks have taken the lead in country frontier technology.

Keywords Efficiency · Meta-frontier - Data envelopment analysis · Double bootstrap · Malaysia

\section{JEL Classification G21 - G28}

\section{Introduction}

Efficiency is the measure of relative performance for decision making units (DMUs). Studying bank efficiency by adopting data envelopment analysis (DEA) is now in common (Paradi and Zhu 2013; Bonanno 2015). In the traditional DEA, performance is calculated using the ex post information (Charnes et al. 1978; Berger and Humphrey 1997). However, Battese and Rao (2002) revealed that examining efficiency with DEA exhibits better discrimination if ex ante information is considered through meta-frontier analysis. Again, literature on DEA suggests that most of the banking studies have considered developed economies as the focus group. Sufian et al. (2014) reported that only a limited research has focused on developing economy like Malaysia. Nevertheless, an extensive analysis of Malaysian bank efficiency using meta-frontier DEA is missing. To the best of authors' knowledge, this is the first study examining efficiency of Malaysian banking settings with meta-frontier DEA.

In the year 2000, Bank Negara Malaysia (BNM) introduced the Financial Sector Master-plan (FSMP) which outlined a three phase plan to restructure the Malaysian financial sector. The restructuring process was involved with major mergers and acquisitions among the existing banks and liberalization of banking sector. The financial sector has experienced successful introduction of dual banking systems (Conventional and Islamic). The expansion of foreign banks in Malaysia has been continuing under the protection of Banking Act 1989. Now, Malaysian banking sector consists of 27 conventional banks and 16 Islamic banks. In the form of ownership structure, Malaysia has 19 local owned and 24 foreign owned commercial banks operating in the country.

The concept of meta-frontier is originated by Hayami (1969). He conceptualized that studying efficiency in comparison basis would become difficult since different technological groups (i.e., local ownership vs. foreign ownership) have been enjoying different set of production factors. For instance, the local banks in Malaysia have been enjoying greater flexibility and government support to capture the market share in lending public sector credit (Cook 2009). But, a large section of bank efficiency literature has found a higher level of efficiency among the foreign 
banks because of their expertise in risk adjustment and capitalization (Gardener et al. 2011; Jeon and Miller 2005). After the economic crises in 1997 and Malaysian financial liberalization, it is imperative to examine the efficiency of Malaysian banks keeping in mind that there is a number of technological groups in Malaysian banking sector (e.g., conventional banks-CBs, Islamic banks-IBs, foreign banks-FBs and local banks-LBs). It is revealed that meta-production function envelops all sub functions and stands as the best efficient one assuming that all the groups have the access in meta-production technology (Battese and Rao 2002). Thus, using metafrontier for examining relative efficiency is justified for Malaysian banking sector.

This paper innovates in this context first by focusing on Malaysian banks, next by applying meta-frontier approach and finally by adopting double bootstrap in a twostage DEA approach. The objectives of the present research are; first, to evaluate relative efficiency among the Malaysian banks. The meta-frontier analysis using DEA is undertaken for the first time in the Malaysian banks. Second, to use the double bootstrap regression as presented by Simar and Wilson (2007) to predict and interpret the role of major contextual variables (IBs, CBs, FBs, LBs, gross domestic product-GDP and inflation) in achieving higher levels of efficiency among the banks. The analysis covers the period from 2009 to 2013 with a balanced panel data of 215 observations.

The remainder of this paper consists of seven sections. Section 2 explains a brief literature on bank efficiency, environmental issues of bank efficiency and metafrontier analysis. Section 3 presents methodological description for the proposed model. Next, Sect. 4 discusses the selection of data and variables. The results and findings are discussed in Sect. 5 followed by the limitations and suggestion for future research in Sect. 6. Section 7 presents the conclusions.

\section{Literature review}

Banks play an important role in economic development through its financial operations-collecting fund form the surplus groups and supplying it among the deficit groups. Thus, the economic performance is often highly linked with banks' efficiency within an economy. As a result, examining bank efficiency has received greater attention by both the academics and researchers over the past decades. The literature of bank efficiency studies thus far mainly focused the developed economies like US and European countries. Only a limited research has focused on developing countries (Sufian et al. 2014; Wanke et al. 2015, 2016a, b). Among these studies, the two main efficiency measurement techniques are non-parametric test and parametric test (Berger and Humphrey 1997). DEA is a non-parametric efficiency measurement technique developed by Charnes et al. (1978). DEA generalizes the single input and single output measure of Farrell (1957) into multiple inputs-outputs measures to evaluate relative efficiency among the DMUs (Charnes et al. 1997). A DMU is considered as an efficient unit if no DMU can produce such outputs without increasing the required inputs. One of the major benefits of using DEA other than the parametric efficiency techniques (the most popular one is stochastic frontier approach-SFA) is that it does not require detailed 
theoretical process knowledge (Cooper et al. 2006). On top of that, the meta-frontier DEA allows separating DMUs based on their specific characteristics.

The use of second stage DEA is now common and advocated by a significant number of papers (Hoff 2007). The most often used regression model for second stage DEA is Tobit analysis for censored dependent variables (Wang 2006). Some commonly used regression for two stage DEA are The Papke-Wooldridge approach (Papke and Wooldridge 1993), The unit-inflated beta model (Cook et al. 2000), OLS (Hoff 2007) and others. Very recently, Wanke and Barros (2016) examined heterogeneity among the Brazilian insurance companies using meta-frontier DEA in a two-stage analysis. In the second stage, data mining is used. Their results reveal that insurance companies have heterogeneous impact based of geographical location and type of insurance. Using data mining in the second stage is also done by Barros and Wanke (2014).

The traditional DEA views the technique as a black box which gets inputs and produces outputs. In contrast, the second stage DEA can examine the sources of inefficiency from the efficiency scores against the predetermined independent variables (Hoff 2007). According to Simar and Wilson (2007) the scores from traditional DEA is combined with two major shortcomings. First, a serial unknown correlation among the results due to the relative scores \& second, the inputs and outputs that have used may have correlations among themselves. As a result, the scores from second stage regression results are inconsistent. Simar and Wilson (2007) presented a long list of two-stage DEA studies and their measurement approaches (i.e., Tobit regression, ordinary least square-OLS, etc.). They proposed a double bootstrapping method which can provide bias adjusted efficiency scores along with consistent inference for our second stage efficiency estimations.

The latest economic meltdown sheds some doubt on proper functioning of the conventional (interest based) banking. The question is what differs between CB and IB? In operation, both the banking systems use the same information (e.g., inflation, price index, customer index) from the market. But, the central concept lies in the best practice of Shariah (i.e., Islamic law and principles) that governs the process of IBs. According to Shariah law, risk must be shared among the stakeholders. In contrast with the $\mathrm{CBs}$, risk needs to be transferred from the savers group to the borrowers group. Such characteristics of IBs, nowadays, appealing non-Muslims as well (Sufian et al. 2008). Therefore, the risk sharing characteristics of IBs along with the striking worldwide growth have increased the academics' interest in comparing the efficiency between these two types of banks (Sufian et al. 2014; Beck et al. 2013; Ariss 2010).

In the aftermath of the latest financial crisis in 2007-08, a number of studies have revealed a mixed type of results studying the relative performances of IBs and CBs. Among the significant ones, Rosman et al. (2014) examined pure and scale efficiency among 79 Islamic banks worldwide. Their findings revealed that IBs are mostly scale efficient (i.e., the size of operations is optimal and any modifications on its size will cause inefficiency). They also argued that IBs are capable of continuing sustainable operations, even in time of world crisis events because of their specialization in profitability and capitalization. In a similar study, Kamarudin et al. (2014) examined cost, revenue, and profit efficiency of 74 banks globally (47 CBs 
and 27 IBs). According to their findings, IBs are advanced in profit efficiency. In contrast to these, Beck et al. (2013) examined 510 banks from 22 countries and found no significance difference in efficiency between these two types of banks. Therefore, we expect that the nature of banks' operation (IBs vs. CBs) might have positive or negative effect on Malaysian bank efficiency.

In recent years, research on bank efficiency with the effect of bank ownership (foreign vs. local) has expanded. The question is does bank efficiency differ for ownership differences? The existing theory implies that the limit of efficiency of these two types of banks differ as a consequence of their inherent characteristics. Berger et al. (2000) described the theory with "global advantage" and "home field advantage". According to global advantage hypothesis, foreign banks in a host country benefited from competitive advantage, use of advanced technology and available workforce. In contrast, the home field advantage hypothesis describes that foreign banks encounter control in operation, production cost or lower revenue for the same financial services when compared to their local peers. Lensink et al. (2008) expanded the theory with "institutional framework" (i.e., the gap between home and host countries' legal and regulatory frameworks). According to them, foreign banks suffer if the host country's institutional framework is poor than the home country. Based on the above theories, earlier research has identified a mixed relationship between bank efficiency and bank ownership. In a survey of 130 articles on bank efficiency, Berger and Humphrey (1997) found that the foreign banks are less efficient in the developed economies. They argued that, it is not the economic status rather the market share of an economy which is served by the foreign banks. However, Jeon and Miller (2005), Sufian (2011) and some recent studies revealed that the foreign banks are found to be more efficient in the developing economies. Therefore, either a positive or negative relationship between bank efficiency and ownership is expected.

There is a profound link between bank efficiency and macroeconomic variables. To capture the influence of country specific issues on Malaysian bank efficiency, we consider the most influential ones; gross domestic product (GDP) and inflation. An extensive literature on GDP and bank efficiency has confirmed that the development of banking sector reflects a long-term economic growth. In addition to that, GDP is also expected to have positive association with bank efficiency since better GDP is likely to have more deposits and higher growth in loans (Dietrich and Wanzenried 2014). While comparing the influence of GDP on foreign and local banks, Williams (2003) revealed that banks prefer to invest in countries with higher profit opportunities. He considered GDP as the measure of profit opportunity. According to his findings, foreign banks are found reluctant in investment if home country GDP is higher than the host country. As a result, local banks increased investment in the host country. Their research supplemented the existing literature on GDP and bank efficiency. Based on the above literature, we expect a positive relation between Malaysian GDP and bank efficiency.

Inflation has significant impact on lending behavior of banks and, in turn, on total banking efficiency. Boyd et al. (2001) examined the effect of inflation on bank efficiency and concluded that an increasing inflation rate can negatively influence banks' ability to allocate its resources. In contrast, Athanasoglou et al. (2008) have 
shown positive relationship between inflation rate and banks' profitability. Again, Perry (1992) pointed a critical issue regarding bank efficiency and inflation rate. He recommended that inflation is of two types-predicted and unpredicted. He empirically proved that bank managers can ensure a higher profitability through a planned deposit creation and asset management by an accurate prediction of inflation. Otherwise, an unpredicted inflation will raise the cost and put the bank in trouble through an unadjusted asset and liability gap crisis. There is a critical pint known as "thresholds points" in the inflation rate. If a high inflation country experienced an inflation rate more than $15 \%$, even a predictable inflation rate cannot help to maintain banks' profitability. According to their theory, the entire economy will encounter a corresponding collapse in financial system. The influence of inflation on bank profitability differs based on ownership too. These mixed results could be attributed differently in case of Malaysia. Therefore, the relationship between inflation and bank efficiency might be positive or negative.

Along with business operations (Islamic vs. conventional), bank ownership (foreign vs. local) and macroeconomics variables as shown above, some bank specific variables have also significant impact on bank efficiency (Sufian and Habibullah 2010; Wanke et al. 2016a; Azad 2015). Based on literature, the following bank specific characteristics are examined in this study: return on asset (ROA), total asset, total deposits, banks liquidity, asset quality, management quality, and capital adequacy. Table 1 briefly explains expected relationship of these variables with Malaysian bank efficiency.

Thus, the following two major research gaps are revealed from the above literature. First, to the best of our knowledge, literally no study has combined metafrontier DEA with double bootstrap regression in second stage to examine bank efficiency in Malaysian settings. Second, Empirical evidence on conventional bank efficiency among the developed economies are saturated. This study will fill the gap by examining comparative performance between (1) Islamic vs. conventional banks and (2) foreign vs. local banks in developing economies like Malaysia.

\section{Methodology}

Oh and Lee (2010) presented three technologies in meta-frontier; (1) contemporaneous distance function, (2) intertemporal distance function and (3) global distance function. With the help of these benchmark technologies we shall be able to measure component distance function as required in meta-frontier technology. Let's assume that there are $(\mathrm{J})$ different technologies within the selected DMUs.

Contemporaneous benchmark technology produces a reference set of $(P)$ at any time period $(t)$. For each group of technology $\left(R_{j}\right)$, the production set is designed as $P_{R_{j}}^{t}=(x, y) \mid x$ produces $y$ and $\lambda P^{t}=P^{t}, t=1, \ldots, T$, and $\lambda>0$. This technology is based on the valued work of Pastor and Lovell (2005). This technology is a simple combination of all the proposed contemporaneous production sets and for all time period $P_{R_{j}}^{\text {InterT }}=\operatorname{conv}\left(P_{R_{j}}^{1} \cup P_{R_{j}}^{2} \cup, \ldots, \cup P_{R_{j}}^{T}\right)$ for a defined technology group $\left(R_{j}\right)$. So, for all the $(J)$ different technologies within the selected DMUs, $(J)$ different 
Table 1 Descriptive of variables

\begin{tabular}{|c|c|c|c|}
\hline Variable & $\begin{array}{l}\text { Short } \\
\text { name }\end{array}$ & Description & $\begin{array}{l}\text { Expected } \\
\text { relationship }\end{array}$ \\
\hline \multicolumn{4}{|l|}{ Bank Specific variables } \\
\hline Return on assets & ROA & $\begin{array}{l}\text { ROA is used as a proxy for explaining Malaysian } \\
\text { bank profitability }\end{array}$ & + \\
\hline Total deposits & MSHAR & $\begin{array}{l}\text { Total deposits are considered as a proxy for market } \\
\text { share of the banks. Prior literature knowledge } \\
\text { has no concrete knowledge on impact of total } \\
\text { deposits on bank efficiency }\end{array}$ & \pm \\
\hline Total assets & SIZE & $\begin{array}{l}\text { Banks' total assets are considered as the proxy for } \\
\text { bank size to capture possible economics of scale- } \\
\text { cost advantage for bank size }\end{array}$ & + \\
\hline $\begin{array}{l}\text { Total loans to total } \\
\text { assets }\end{array}$ & LIQ & $\begin{array}{l}\text { The ratio of total loans to total assets is considered } \\
\text { as the proxy of banks liquidity which has proven } \\
\text { positive relationship with bank efficiency }\end{array}$ & + \\
\hline $\begin{array}{l}\text { Non-interest income to } \\
\text { total assets }\end{array}$ & DIVERSI & $\begin{array}{l}\text { Bank's income is a composite of income from } \\
\text { different sources. Thus the more the diversified } \\
\text { income he less pressure on banks interest income } \\
\text { and hence, the interest sensitivity reduces }\end{array}$ & \pm \\
\hline $\begin{array}{l}\text { Book value of } \\
\text { shareholders equity } \\
\text { to total assets }\end{array}$ & CAPADQ & $\begin{array}{l}\text { Total book value of shareholders equity to total } \\
\text { assets is used as the proxy of capital adequacy. } \\
\text { This variable is particularly an interest of } \\
\text { regulators }\end{array}$ & + \\
\hline $\begin{array}{l}\text { Non-interest expenses } \\
\text { to total assets }\end{array}$ & MGTQ & $\begin{array}{l}\text { Non interest expenditure is associated with } \\
\text { management quality. Hence the non-interest } \\
\text { expenses to total assets are used as a proxy for } \\
\text { management quality in this study }\end{array}$ & - \\
\hline $\begin{array}{l}\text { Loan-loss provision to } \\
\text { total assets }\end{array}$ & ASSQ & Is used as a proxy for asset quality & - \\
\hline \multicolumn{4}{|l|}{ Macroeconomic variables } \\
\hline $\begin{array}{l}\text { Gross domestic } \\
\text { product }\end{array}$ & GDP & $\begin{array}{l}\text { Gross domestic product is used as the proxy for } \\
\text { overall economic condition and thus, a positive } \\
\text { relationship is expected }\end{array}$ & + \\
\hline GDP growth & GDPGTH & $\begin{array}{l}\text { Is used as a proxy for future GDP estimation and } \\
\text { opportunity in business expansion }\end{array}$ & + \\
\hline Inflation & INF & $\begin{array}{l}\text { Inflation is used as a proxy for economic condition } \\
\text { and a negative association with banks' efficiency } \\
\text { is expected }\end{array}$ & - \\
\hline \multicolumn{4}{|l|}{ Bank Ownership } \\
\hline Local banks & LB & & - \\
\hline Foreign banks & FB & & + \\
\hline \multicolumn{4}{|l|}{ Bank nature } \\
\hline Islamic banks & IB & & + \\
\hline Conventional banks & $\mathrm{CB}$ & & - \\
\hline
\end{tabular}


intertemporal benchmarks will be produced. Finally, global technology for all time period is $P_{R_{j}}^{\text {Global }}=\operatorname{conv}\left(P_{R_{1}}^{\text {InterT }} \bigcup P_{R_{2}}^{\text {InterT }} \bigcup, \ldots, \cup P_{R_{J}}^{\text {InterT }}\right)$.

Starting with the basic Malmquist index (MI) model of Caves et al. (1982), a contemporaneous MI would be:

$$
M I^{s}\left(x^{t}, y^{t}, x^{t+1}, y^{t+1}\right)=\frac{D^{s}\left(x^{t+1}, y^{t+1}\right)}{D^{s}\left(x^{t}, y^{t}\right)}
$$

where the production set is $P_{R_{j}}^{s}, s=t, t+1$ for $R_{j}$ and the distance function $D^{s}(x, y)=\inf \left\{\phi>0 \mid \frac{x, y}{\phi} \in P_{R_{j}}^{s}\right.$. Fare et al. (1994) proposed that MI as the geometric mean of MI of two periods since $M^{t}\left(x^{t}, y^{t}, x^{t+1}, y^{t+1}\right) \neq M I^{t+1}\left(x^{t}, y^{t}, x^{t+1}, y^{t+1}\right)$. With this connection, for an intertemporal benchmark technology, the distance function is:

$$
M I^{I}\left(x^{t}, y^{t}, x^{t+1}, y^{t+1}\right)=\frac{D^{I}\left(x^{t+1}, y^{t+1}\right)}{D^{I}\left(x^{t}, y^{t}\right)} .
$$

Here, the production set is $P_{R_{j}}^{I}, I=t$ for a group of $R_{j}^{I}$ and the distance function $D^{I}(x, y)=\inf \left\{\phi>0 \mid \frac{x, y}{\phi} \in P_{R_{j}}^{I}\right.$. Based on the valued work of Pastor and Lovell (2005), any intertemporal distance function can be decomposed as follow:

$$
\begin{aligned}
M I^{I}\left(x^{t}, y^{t}, x^{t+1}, y^{t+1}\right) & =\frac{D^{t+1}\left(x^{t+1}, y^{t+1}\right)}{D^{t}\left(x^{t}, y^{t}\right)} \times\left\{\frac{D^{I}\left(x^{t+1}, y^{t+1}\right)}{D^{t+1}\left(x^{t+1}, y^{t+1}\right)} \times \frac{D^{t}\left(x^{t}, y^{t}\right)}{D^{I}\left(x^{t}, y^{t}\right)}\right\} \\
& =\frac{T E f f^{t+1}}{T E f f^{t}} \times \frac{B P G p^{t+1}}{B P G p^{t}}=E C \times B P G .
\end{aligned}
$$

Here, $T E f f^{s}$ and $B P G p^{s}$ are the technical efficiency and best practice respectively. $E C$ denotes measure in change of efficiency proposed by Fare et al. (1994). BPG denotes the changes in best practice technology gap between the contemporaneous and intertemporal production possibility frontier. $B P G>1$ Refers that the contemporaneous frontier of $t+1$ is closer than the intertemporal benchmark technology for the time $t$, and $B P G<1$ is vice versa. Pastor and Lovell (2005) proposed this change as just the technical change a technology within a defined group. This is also the equivalent of technical progress or regress as presented by Caves et al. (1982). Let's defined in production set of $P^{\text {Global }}$ as:

$$
M I^{\text {Global }}\left(x^{t}, y^{t}, x^{t+1}, y^{t+1}\right)=\frac{D^{\text {Global }}\left(x^{t+1}, y^{t+1}\right)}{D^{\text {Global }}\left(x^{t}, y^{t}\right)},
$$

here, the production set is $P_{R_{j}}^{\text {Global }}, I=t$ for all groups of $R_{J}^{s}$ and the distance function $D^{\text {Global }}(x, y)=\inf \left\{\phi>0 \mid \frac{x, y}{\phi} \in P^{\text {Global }}\right\}$ known as global technology set. Using the same technology of Eq. 1 for MI, decomposition of a global set can be shown as follows: 


$$
\begin{aligned}
& \text { MI Global }\left(x^{t}, y^{t}, x^{t+1}, y^{t+1}\right) \\
& =\frac{D^{t+1}\left(x^{t+1}, y^{t+1}\right)}{D^{t}\left(x^{t}, y^{t}\right)} \times\left\{\frac{D^{t}\left(x^{t}, y^{t}\right)}{D^{t+1}\left(x^{t+1}, y^{t+1}\right)} \times \frac{D^{\text {Global }}\left(x^{t+1}, y^{t+1}\right)}{D^{G l o b a l}\left(x^{t}, y^{t}\right)}\right\} \\
& =\frac{T E f f^{t+1}}{T E f f} \times \frac{B P G p^{t+1}}{B P G p^{t}} \times \frac{T G p R^{t+1}}{T G p R^{t}}=E C \times F C \times T G R .
\end{aligned}
$$

Here $E C F C$, and $T G R, s=t, t+1$, are the technical efficiency level, technology gap for the best practice and level of technological gap ratio respectively.

The distance function for $k^{\prime} \in R_{j}$ for the period of $s=t, t+1$,

$$
\left(D^{s}\left(x^{k^{\prime}, s}, y^{k^{\prime}, s}\right)\right)^{-1}=\max \phi_{c}^{k^{\prime}, s} .
$$

Subject to:

$$
\begin{gathered}
\sum_{k \in R_{j}} z^{k, s} y_{m}^{k, s} \geq \phi_{c}^{k^{\prime}, s} y_{m}^{k^{\prime}, s}, \quad m=1 \ldots \ldots . . M \\
\sum_{k \in R_{j}} z^{k} x_{n}^{k, s} \leq x_{n}^{k^{\prime}, s}, \quad n=1 \ldots \ldots \ldots N \\
z^{k, s} \geq 0
\end{gathered}
$$

where $z^{k}$ is the intensity variable of a DMU, in our case each bank is a unit. Using Eq. 6, the intertemporal distance functions $D^{I}\left(x^{k^{\prime}, s}, y^{k^{\prime}, s} / D^{k^{\prime}, s}\left(x^{k^{\prime}, s}, y^{k^{\prime}, s}\right), s=t, t+1\right.$ are calculated using the following calculation:

$$
\left[D^{I}\left(x^{k^{\prime}, s}, y^{k^{\prime}, s} / D^{k^{\prime}, s}\left(x^{k^{\prime}, s}, y^{k^{\prime}, s}\right)\right]^{-1}=\max \phi_{I}^{k^{\prime}} .\right.
$$

Subject to:

$$
\begin{gathered}
\sum_{k \in R_{j}, s \in \tau} z^{k} y_{m}^{k} \geq \phi_{I}^{k^{\prime}} \hat{\phi}_{c}^{k^{\prime}, s} y_{m}^{k^{\prime}, s}, \quad m=1 \ldots \ldots . . M \\
\sum_{k \in R_{j}, s \in \tau} z^{k, s} x_{n}^{k, s} \leq x_{n}^{k^{\prime}, s}, \quad n=1 \ldots \ldots \ldots N \\
z^{k, s} \geq 0, \quad \tau=(1,2, \ldots ., T) .
\end{gathered}
$$

This equation examines all units of all time period for any specific group $R_{j}$. Now, the following objective function is responsible for calculating objective function for all units, all periods and for all groups in any study. Denoting the solution of Eq. 7, the global distance function $D^{\text {Global }}\left(x^{k^{\prime}, s}, y^{k^{\prime}, s} / D^{k^{\prime}, s}\left(x^{k^{\prime}, s}, y^{k^{\prime}, s}\right), s=\right.$ $t, t+1$ may calculate as follow: 


$$
\left[D^{\text {Global }}\left(x^{k^{\prime}, s}, y^{k^{\prime}, s} / D^{k^{\prime}, s}\left(x^{k^{\prime}, s}, y^{k^{\prime}, s}\right)\right]^{-1}=\max \phi_{\text {Global }}^{k^{\prime}} .\right.
$$

Subject to:

$$
\begin{gathered}
\sum_{k \in R_{j, s} \in \tau} z^{k} y_{m}^{k} \geq \phi_{\text {Global }}^{k^{\prime}} \hat{\phi}_{I}^{k^{\prime}, s} y_{m}^{k^{\prime}, s}, \quad m=1 \ldots \ldots . M \\
\sum_{k \in R_{j, s} \in \tau} z^{k, s} x_{n}^{k, s} \leq x_{n}^{k^{\prime}, s}, \quad n=1 \ldots \ldots . . . \\
z^{k, s} \geq 0, R=R_{1} \bigcup R_{2} \bigcup R_{3}, \ldots, \bigcup R_{J}, \quad \tau=(1,2, \ldots, T) .
\end{gathered}
$$

Using Eqs. 6, 7 and 8, the optimal solution for Malmquist meta-frontier index can be calculated and decomposed.

This technological gap ratio (TGR) was introduced and empirically used by Battese et al. (2004). This ratio identifies the gap between different technologies groups used in sampling with the global technology set. The efficiency change ratio (EC) was named as pure technological catch-up by Chen and Yang (2011). A value larger than one implies the shrinkage of the technology gap (an increase in TGR). The technological change ratio (FC) is the meta-frontier shift relative to the groupfrontier shift. Chen and Yang (2011) named this as frontier catch-up. A value larger than $1(\mathrm{FC}>1)$ implies a larger progress in the meta-frontier than that in the groupfrontier. Finally, the Malmquist index is also known as technology gap ratio change (TGR) named by (Chen and Yang 2011). This is also the product of efficiency change ratio (EC) and technological change ratio (FC).

In order to identify the most influential environmental factors that are contributing to Malaysian banking efficiency, the following regression model is estimated:

$$
\begin{aligned}
\text { Efficiency }_{j}= & \beta_{0}+\beta_{1} \sum \text { Bankspecific }+\beta_{2} \sum \text { Macroeconomic } \\
& +\beta_{3} \sum \text { Ownership }+\beta_{4} \sum \text { Nature }+\varepsilon_{j t} .
\end{aligned}
$$

Here, Efficiency $y_{j}$ is the Farrell's bias-corrected efficiency score of the $j$ th bank that derived from meta-frontier DEA analysis in the earlier section. We capture the governance issue in both the foreign owned banks and local banks in Malaysia using a binary dummy variable set and included in the regression estimates. The independent variables as shown in Eq. 9 are described earlier in Sect. 2.

We follow algorithm \#2 from Simar and Wilson (2007) to calculate the double bootstrap using FEAR package in R software pioneered by Wilson (2008). First we use "trunk.reg" command to run a truncated normal regression with the maximum likelihood method. Second, we command "rnorm.trunc" in FEAR to achieve the random deviations. Next, we calculate bias-corrected efficiency scores with the results from bootstrap. Then, we run a second stage regression using the biascorrected efficiency results. Fifth, we run another (double) bootstrap regression based on the achieved efficient results in earlier stage. Finally, to estimate marginal 
effect of contextual variables we construct a bootstrap with $95 \%$ confidence intervals.

\section{Data and variables}

While there continues to be a debate in the selection of bank inputs and outputs, we adopt all three available approaches for capturing the true nature of bank business. First, the production approach pioneered by Benston (1965) commonly views a bank as a producer of bank services. This approach explains both financial and nonfinancial activities of a bank. In contrast, Sealey and Lindley (1977) proposed intermediation approach that examines bank's capacity in transforming deposits into loans and advances. Intermediation approach examines how much progress or regress a bank has achieved in the ever challenging environment by producing profit out of its inputs? Paradi and Zhu (2013) revealed that this approach examines bank's ability of "going concern". By the term "going concern", it assumes that a bank will function without the threat of liquidation for the likely future. Again, Fethi and Pasiouras (2010) found that major studies in bank DEA have used profitability model. The correctness of each approach is largely dependent to a number of environmental issues as well as to the appropriate circumstances (Wagner and Shimshak 2007). We strongly consider that a bank does all of the above tasks simultaneously and hence deem a comparative study using all three approach. The input and output variables are listed in Table 2. The selection of each of the variables has literature significance and has been used in previous studies (Paradi and Zhu 2013). The descriptive statistics of the variables are shown in Table 3. All are expressed in MYR-Malaysian real rates.

We use panel data of all Malaysian banks over the period 2009-2013 published in annual reports, BankScope database and reports from the Bank Negara Malaysia. The macroeconomic data for the double bootstrap regression is obtained from the annual reports of Bank Negara Malaysia. The final sample consists of 10 local Islamic banks-LIBs, 8 local conventional banks-LCBs, 6 foreign Islamic banksFIBs, and 19 foreign conventional banks-FCBs yielding a total of 215 bank-year observations. Table 2 describes the summary statistics of variables that are used in this study. For the IBs, profit is as equivalent of interest income for $\mathrm{CBs}$, not by the process just as a meaning.

Table 2 Selection of inputs and outputs for DEA

\begin{tabular}{|c|c|c|c|c|c|}
\hline \multicolumn{2}{|c|}{ Production approach } & \multicolumn{2}{|c|}{ Profitability approach } & \multicolumn{2}{|c|}{ Intermediation approach } \\
\hline Inputs & Outputs & Inputs & Outputs & Inputs & Outputs \\
\hline Interest expenses & $\begin{array}{l}\text { Interest } \\
\text { income }\end{array}$ & Total Capital & $\begin{array}{l}\text { Total } \\
\text { deposits }\end{array}$ & Total capital & $\begin{array}{l}\text { Total } \\
\text { loans }\end{array}$ \\
\hline Salary expenses & Net income & Salary expenses & Total loans & Total deposits & \\
\hline $\begin{array}{l}\text { Operating } \\
\text { expenses }\end{array}$ & & $\begin{array}{l}\text { Interest } \\
\text { expenses }\end{array}$ & & $\begin{array}{l}\text { Salary } \\
\text { expenses }\end{array}$ & \\
\hline
\end{tabular}




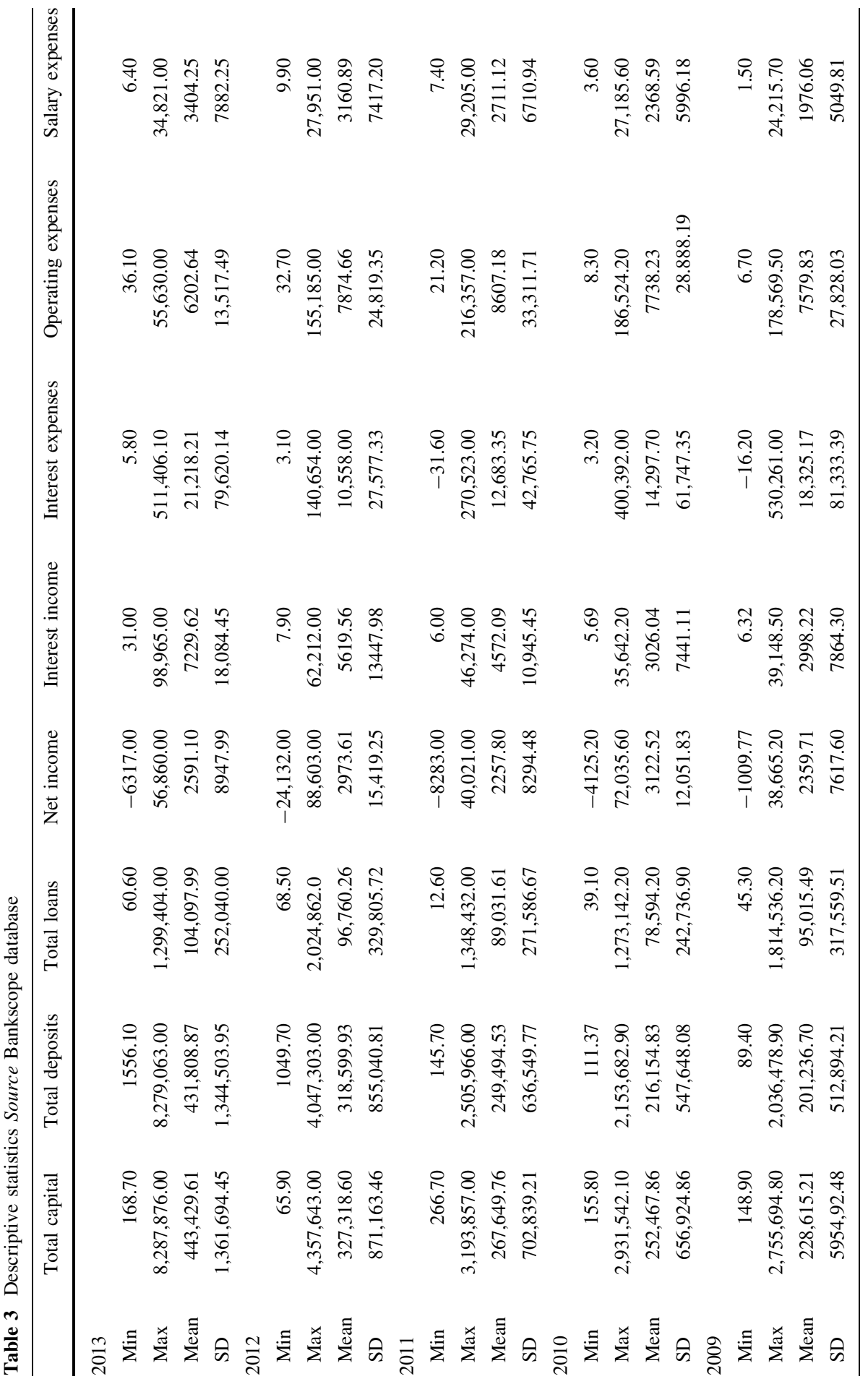




\section{Results and discussions}

Before examining efficiency of selected banks, it is imperative to determine the number of groups. It must also be confirmed that each DMUs belongs to the predetermined groups. Classification among the groups is subject to research objectives. Hence, a different category may disclose contradictory results compared to ours. Nevertheless, the following results must read along with our classification of technology only (i.e., LIBs, LCBs, FIBs, and FCBs).

The empirical results from Table 4 reveal that there is a significant deviation among the productivity, technological frontier and efficiency scores in all three business approaches for our 18 local (conventional and Islamic) banks. Examining the productivity scores among the local banks, as presented in Table 4, local banks, on an average, are found to be average productive at any approaches. The highest productivity for local banks is observed in production approach. And, the productivity among the local banks is lowest if we examine them using intermediation approach. In all aspects, there is not a big difference between efficiency results between LCBs and LIBs. Another interesting finding is that the efficiency of local banks' (both Islamic and conventional) are found to be progressed over the period. In particular, LIBs' efficiency progresses are found to be higher than LCBs in all approaches. And, there is no significant deviation among the EC scores within these three approaches.

The measure of technical change, denoted as FC, describes a DMUs' technical change; i.e., how far or how close a DMU moves from or to its group frontier. In all aspects, excepting LIBs in profitability approach, Malaysian local banks are found, on an average, more than unity. This means that local banks are technically progressed over the period. The highest technical progress in observed for LIBs when they have calculated using intermediation approach. The measure of how much a DMU gets closer to or farther away from the country frontier technology, i.e., TGR, reveals that local banks in Malaysia are progressing to its country frontier in all together. Comparing between LIBs and LCBs, it is found that LCBs are higher change in both profitability and intermediation approach. However, LIBs are found to have higher progress in production approach. The highest TGR is noticed in case of LCBs in profitability approach.

The yearly change in EC among the LIBs and LCBs are presented in Fig. 1. It is evident from the figure that there is a significant deviation among the three approaches we calculated for these banks. Such mixed results among the approaches show strong evidence that using any individual approach for measuring bank efficiency may result partial evidence and may mislead for potential benchmarking.

Now, the productivity scores and their decomposition of efficiency results of foreign owned Islamic and conventional banks are presented in Table 5. They are also presented in three approaches. Productivity scores among the foreign banks are found less than unity. However, in all approaches, the average MI results of FIBs are higher than the FCBs. The highest average productivity is found for FIBs with $95.9 \%$. A significant difference is observed in case of efficiency scores compared to productivity change. I all approaches, on an average, efficiency scores of FCBs are 


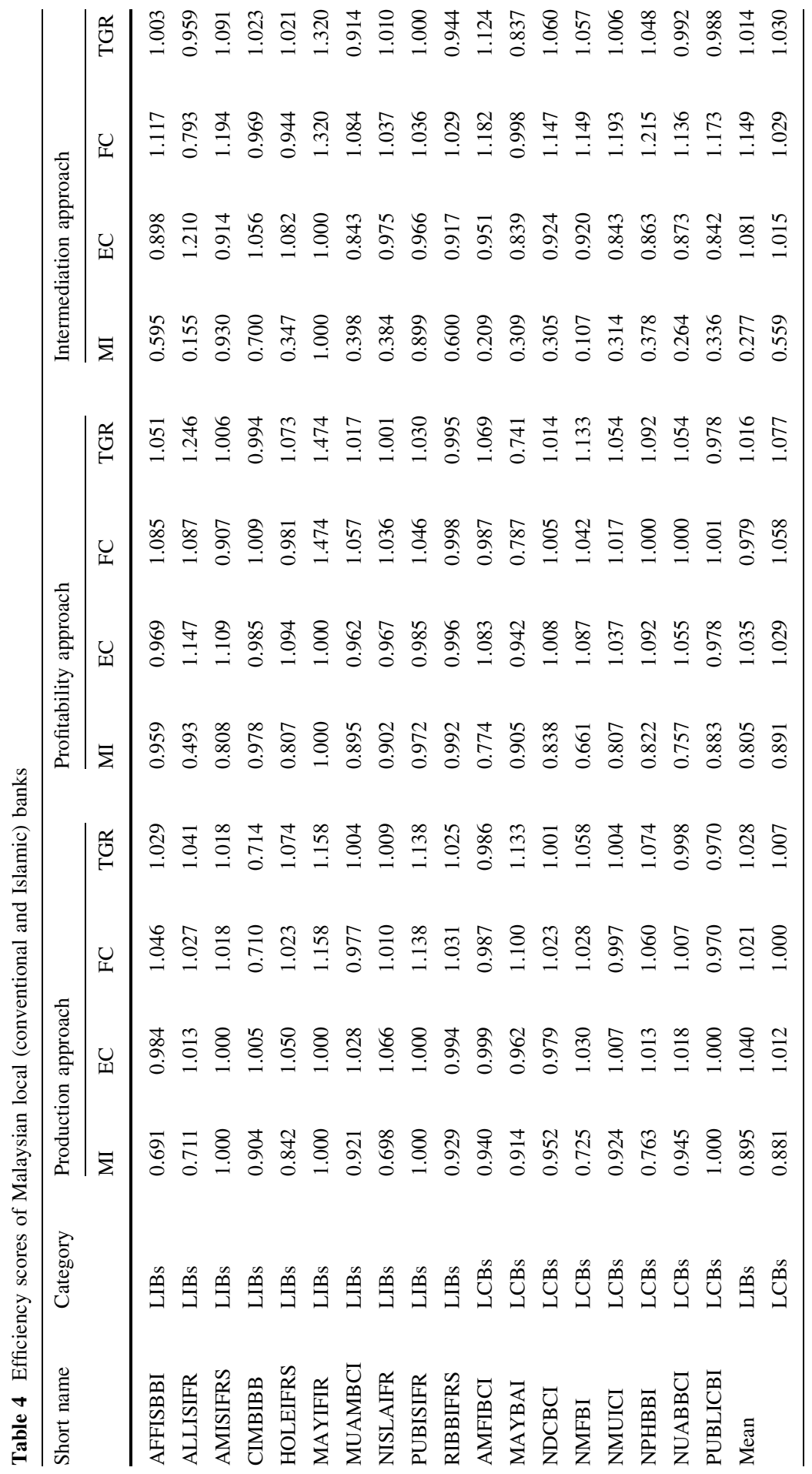



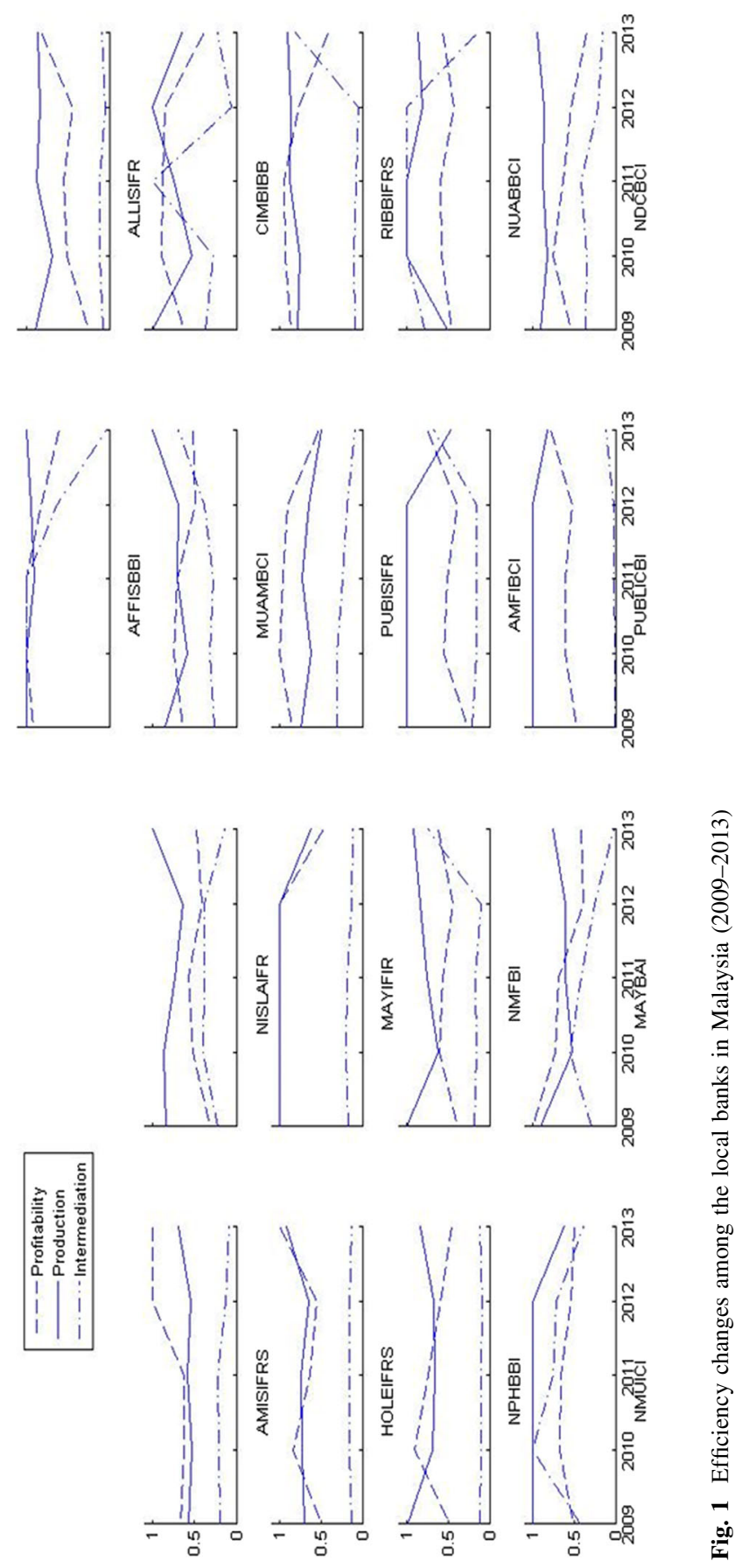


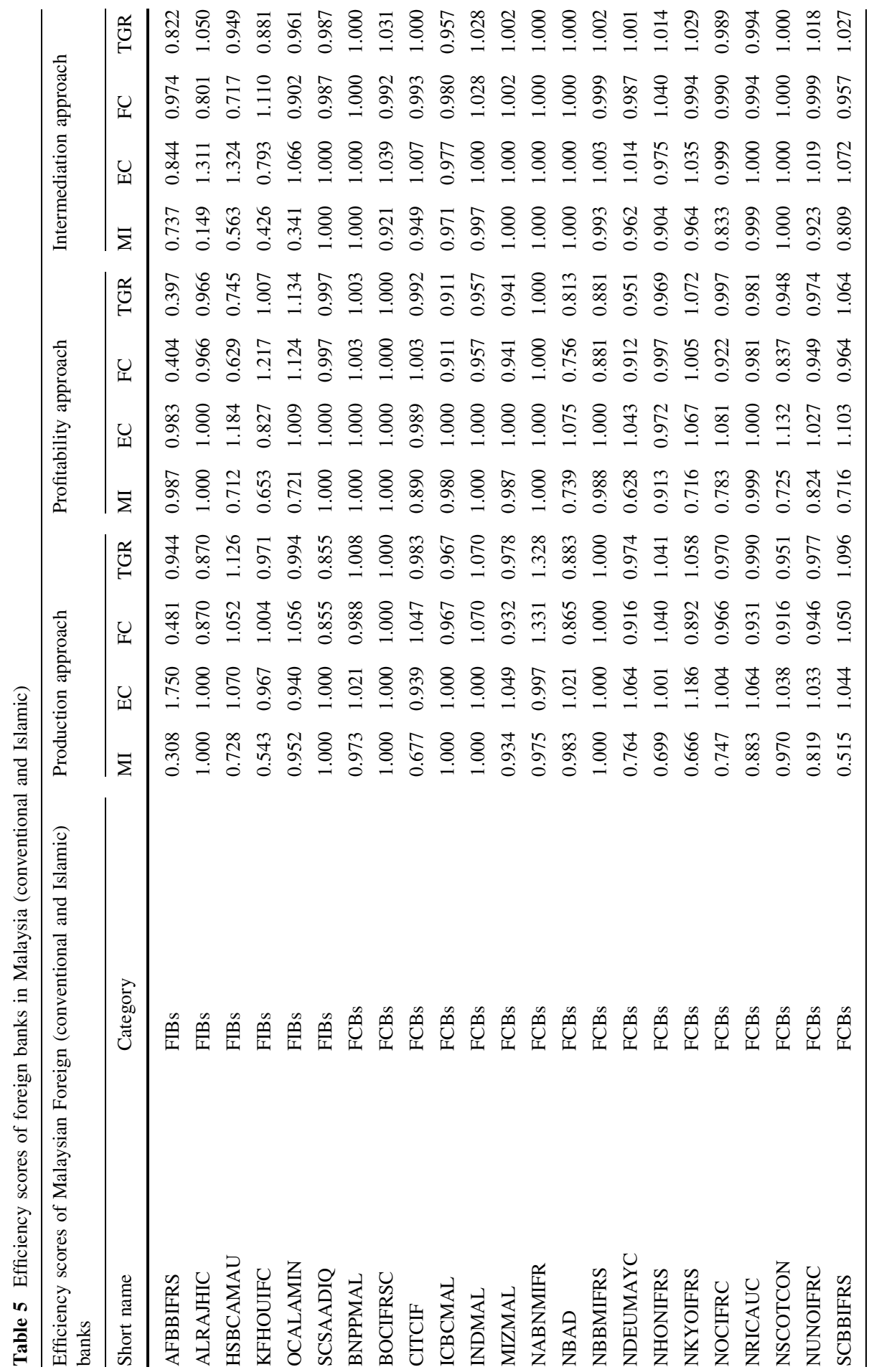




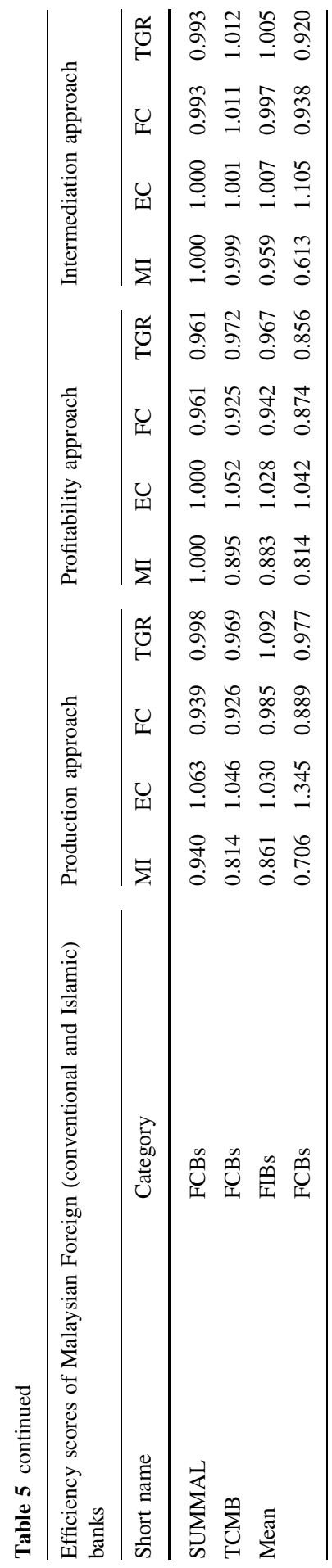



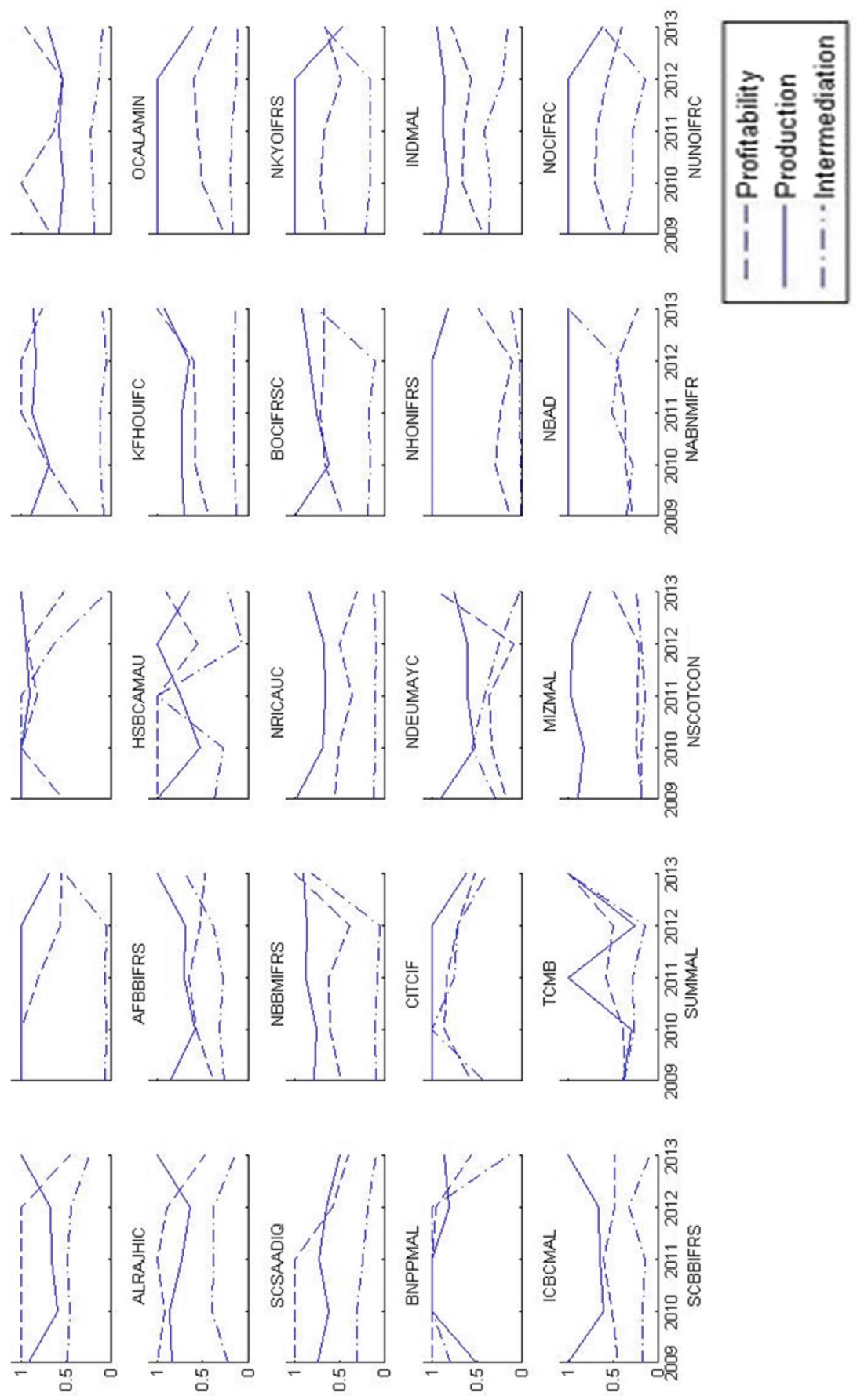

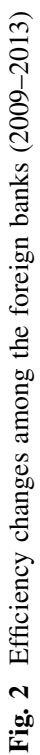


Table 6 Differences in efficiency scores among the groups

\begin{tabular}{lclll}
\hline & LIBs & LCBs & FIBs & FCBs \\
\hline Average efficiency & & & & \\
$\quad$ Production approach & 1.040 & 1.012 & 1.030 & 1.345 \\
Profitability approach & 1.035 & 1.029 & 1.028 & 1.042 \\
$\quad$ Intermediation approach & 1.081 & 1.015 & 1.007 & 1.105 \\
No. of efficient banks & & & & \\
Production approach & 8 & 5 & 4 & 17 \\
Profitability approach & 1 & 6 & 4 & 17 \\
Intermediation approach & 4 & 0 & 4 & 16 \\
Total number of banks & 10 & 8 & 6 & 19 \\
\hline
\end{tabular}

Table 7 Results from double bootstrap estimation

\begin{tabular}{|c|c|c|c|}
\hline \multirow[t]{2}{*}{ Item } & \multirow[t]{2}{*}{ Bias-adjusted Coefficient } & \multicolumn{2}{|c|}{$95 \%$ Bootstrap confidence interval } \\
\hline & & Lower & Upper \\
\hline ROA & $0.0361 *$ & 0.0161 & 0.0661 \\
\hline MSHAR & $-0.0014 *$ & -0.0001 & -0.0501 \\
\hline SIZE & 0.0098 & 0.0017 & 0.0104 \\
\hline LIQ & -0.0040 & -0.0003 & -0.0152 \\
\hline DIVERSI & $0.0212 *$ & 0.0114 & 0.0319 \\
\hline CAPADQ & -0.0171 & -0.0001 & -0.0247 \\
\hline MGTQ & 0.0329 & 0.0117 & 0.0622 \\
\hline ASSQ & 0.0091 & 0.0031 & 0.0196 \\
\hline IB & -0.0783 & -0.0944 & -0.0621 \\
\hline FB & $0.0417 *$ & -0.0268 & 0.0597 \\
\hline $\mathrm{CB}$ & 0.0458 & 0.0124 & 0.0616 \\
\hline IB & $0.0081 *$ & 0.0061 & 0.0078 \\
\hline GDP & $0.0019 *$ & 0.0012 & 0.0027 \\
\hline GDPG & $0.0023 *$ & 0.0003 & 0.0043 \\
\hline INF & -0.0414 & -0.0717 & 0.0196 \\
\hline
\end{tabular}

* Significance at the $5 \%$ level

found higher than that of FIBs. The highest average efficiency progress is observed in case of production approach.

The average technical changes among the foreign Islamic and conventional banks are also mixed. The scores are significantly deviated in all three approaches for all the foreign banks in our study. Comparing technical changes among the foreign banks over the years, it is seen that, on an average, FIBs are progressing towards the group frontier speeder than the FCBs. Finally, the frontier changes of foreign banks are attributed in TGR. The results from FIBs reveal that FIBs have, on an average, TGR higher than those of FCBs. In case of production and 
intermediation approaches, the changes are scored higher than unity. However, in time of profitability approach, the TGR of FIBs are scored less than unity. For the FCBs, TRG are scored all time less than unity.

The differences in yearly efficiency scores among the foreign banks from all three approaches are presented in Fig. 2. It is clearly evident that efficiency scores among the banks have significantly deviated over the years. Hence, using any single approach to explain bank efficiency may lead to faulty benchmarking.

We summarize the above results from all three approaches based on efficiency changes among the selected groups in Table 6. The differences in efficiency scores among the banks significantly deviated in all three groups. Similarly, as we can see in Table 6, based on the approaches, the number of banks as efficient unit has also deviate over the time.

The estimations using Eq. 9 are reported in Table 7. The bias-corrected coefficients are presented in second column. The associated $95 \%$ confidence bands are also listed. The coefficients of first four variables are directly interpretable as the shifts in percentage efficiency scores. Total six out of fifteen independent variables are statistically significant at $5 \%$ levels. The profitability indicator of Malaysian banks (ROA) is found positive impact on efficiency at the $5 \%$ level. A similar and noteworthy finding of this study is that Malaysian bank efficiency is positively linked with income diversification (DIVERSI). This particular result signifies that Malaysian banks are endowed with earning management. Hence, interest sensitivity of Malaysian banks reduces. Market share (MSHAR) of Malaysian banks is also found significantly associated variable among the bank specific variables. The negative relationship between efficiency and total deposit refers that customers are prone to higher return from their deposits and thus, banks are dealing with higher cost involvement in deposit collection.

The coefficient of foreign ownership remains positive and significant indicating that foreign banks have higher efficiency. This finding is consistent with Lensink et al. (2008). In contrast, the coefficient of local ownership is positive but not significant indicating that local ownership has no influence in efficiency. This particular finding is consistent with the earlier studies of Athanasoglou et al. (2008). The coefficient concerning the relationship between conventional bank nature and bank efficiency is also found to be not significant but positive indicating that being conventional bank, there is no influence in bank efficiency. Whereas, the coefficient of Islamic bank nature is positive and found to be significant. Thus, this result indicates that having Islamic bank nature in Malaysia can achieve efficiency. Such a finding is contradictory (i.e., cost inefficient) with the earlier result of Beck et al. (2013). This can be an effect of social values and customer orientation with home field advantage particularly in Malaysian settings (Sufian et al. 2008; Sufian and Kamarudin 2015). Finally, the coefficient of GDP is positive and significant indicating that having a favorable economic growth can lead to an efficiency progress among the banks which is consistent with the earlier results (Gardener et al. 2011). Finally, the regression results support that inflation has negative influence on bank efficiency, since the coefficient is found negative but not significant indicating that even if the economy suffers inflation, bank managers can still operate efficiently by taking appropriate measure at an earlier stage. This result 
is also consistent with the earlier results (Perry 1992; Dietrich and Wanzenried 2014).

\section{Limitations and future research}

Banks' heterogeneity is a major concern for benchmarking bank efficiency. The diverse nature of bank business and the complexity in defining bank variables make the efficiency calculation even difficult. The unobserved variables have significant influence on banks' efficiency. Therefore, using principal component analysis in selection of variables may reduce complexity. Moreover, in order to examine the contextual variables, generalized method of moment (GMM) may explain the fixed effect of short panel data with a large number of observations. Last but not least, bank specific, country specific, governance and other contextual variables may examine in second stage analysis.

\section{Conclusions}

This paper compares four groups of banks' efficiency (i.e., LIBs, LCBs, FIBs, and FCBs) in Malaysian context by adopting the Malmquist meta-frontier total productivity index. First, this paper empirically examines the heterogeneity in Malaysian banking system using three business approaches (i.e., production, intermediation, and profitability) and scrutinizes the deviation in banks' efficiency. In the second stage, bank efficiency scores are tested using the double bootstrap pioneered by Simar and Wilson (2007) to capture the influences of contextual variables (bank specific, bank ownership, bank nature and macroeconomic).

The empirical findings of this paper reveal that foreign Islamic banks are the leading group in all the three business approaches. Such a result signifies the advanced capacity of foreign banks in risk mitigation (Sufian 2011; Lensink et al. 2008), investment portfolio and capacity of adjusting liquidity. Even, in case of profitability and intermediation approaches, the LCBs are not found to be the leading group. In the context of Malaysian present bank regulations, existing discriminations and government restrictions on foreign bank ownership, the results reveal that even with the favorable business condition (Jeon and Miller 2005), Malaysian LCBs did not perform well. Most fundamental finding of this study is that Malaysian Islamic banks are found to be efficient than the local conventional banks. In all the three approaches, the IBs outperform the CBs. This may explain IBs' ability of taking higher risk, higher capitalization and profitability (Sufian and Kamarudin 2015; Sufian et al. 2014).

Studying the effect of contextual variables, this paper finds that local and conventional banks have no influence in the banking efficiency along with inflation. However, Islamic bank nature, foreign bank ownership and GDP have significant positive impact on Malaysian banking sector. The merit attention is observed for bank nature (Islamic banking), GDP and foreign ownership of banking. These findings are similar to the earlier findings (Sufian and Kamarudin 2015; Gardener 
et al. 2011). Embedded within the observed results, it is also be highlighted the prospective trend and future possibilities of Malaysian Islamic banking as a whole (Sufian and Kamarudin 2015; Beck et al. 2013; Ariss 2010; Sufian et al. 2008). Among the bank specific variables, bank profitability and income diversification are found positively linked with Malaysian bank efficiency while market share (total deposit) is found have negative influence in efficiency. These results are significant at $5 \%$ level.

The contributions of this paper are as follows. Firstly, this paper explains and empirically presents the importance of using various business approaches (production, profitability and intermediation) to describe bank efficiency. The findings of this paper suggested that efficiency scores varies with respect to variable and approach selection. Considering the effect of business cycle, profitability approach should be worthwhile. So, in case of any event of national or international financial crisis, using profitability approach can better explain bank performance. Next, intermediation approach should be suitable to examine bank performance using a longer time series data since the concept of intermediation lies into the "going concern" concept (Paradi and Zhu 2013). This refers to the ability of a bank to convert deposits into loans. The production approach gives a holistic idea of banks' ability to serve a society by producing both financial and nonfinancial activities. Hence, in order to know the ability of a bank to serve its economy, production approach is suitable. Secondly, banks' heterogeneity is considered and the existing meta-frontier method is used with the above business approaches to measure bank efficiency.

From the managerial perspective, this paper contributes by examining bank efficiency using both the business approaches and contextual variables. This paper also serves as the ground breaking benchmarking tool to explain the diverse aspects of banking business. This paper suggests that for attaining bank efficiency managers should not only to focus on their peer groups but also to business approaches. A bank might be efficient in profit approach but may not be efficient in other conditions or has less capacity in intermediation through attaining scale of economics or in production of loan. A particular finding of this paper is that the managers can benchmark bank's efficiency comparing both the peer banks in different study groups and within banks operational approaches.

\section{Compliance with ethical standards}

Conflict of interest The authors declare that they have no conflict of interest.

\section{Appendix}

See Table 8 . 
Table 8 Selected banks and their short name

\begin{tabular}{|c|c|c|c|}
\hline Short name & Foreign bank & Short name & Local Bank \\
\hline AFBBIFRS & United Overseas Bank Bhd. & AFFISBBI & Bangkok Bank Berhad \\
\hline ALRAJHIC & $\begin{array}{l}\text { Al Rajhi Banking \& Investment } \\
\text { Corporation Berhad }\end{array}$ & ALLISIFR & Bank of America Malaysia Berhad \\
\hline HSBCAMAU & Asian Finance Bank Berhad & AMISIFRS & Bank of China Berhad \\
\hline KFHOUIFC & $\begin{array}{l}\text { HSBC Amanah Malaysia } \\
\text { Berhad }\end{array}$ & CIMBIBB & $\begin{array}{l}\text { Bank of Tokyo-Mitsubishi UFJ } \\
\text { (Malaysia) Berhad }\end{array}$ \\
\hline OCALAMIN & Kuwait Finance House Berhad & HOLEIFRS & BNP Paribas Malaysia Berhad \\
\hline SCSAADIQ & OCBC Al-Amin Bank Berhad & MAYIFIR & Citibank Berhad \\
\hline BNPPMAL & $\begin{array}{l}\text { Standard Chartered Saadiq } \\
\text { Berhad }\end{array}$ & MUAMBCI & Deutsche Bank Berhad \\
\hline BOCIFRSC & Affin Bank Berhad & NISLAIFR & HSBC Bank Malaysia Berhad \\
\hline CITCIF & Alliance Bank Malaysia Berhad & PUBISIFR & India International Bank Berhad \\
\hline ICBCMAL & AmBank Berhad & RIBBIFRS & $\begin{array}{l}\text { Industrial and Commercial Bank of } \\
\text { China (Malaysia) Berhad }\end{array}$ \\
\hline INDMAL & CIMB Bank Berhad & AMFIBCI & J.P. Morgan Chase Bank Berhad \\
\hline MIZMAL & Hong Leong Bank Berhad & MAYBAI & Mizuho Bank Berhad \\
\hline NABNMIFR & Malayan Banking Berhad & NDCBCI & $\begin{array}{l}\text { National Bank of Abu Dhabi } \\
\text { Malaysia Berhad }\end{array}$ \\
\hline NBAD & Public Bank Berhad & NMFBI & OCBC Bank Berhad \\
\hline NBBMIFRS & RHB Bank Berhad & NMUICI & $\begin{array}{l}\text { Standard Chartered Bank Malaysia } \\
\text { Berhad }\end{array}$ \\
\hline NDEUMAYC & Affin Islamic Bank Berhad & NPHBBI & $\begin{array}{l}\text { Sumitomo Mitsui Banking } \\
\text { Corporation Malaysia Berhad }\end{array}$ \\
\hline NHONIFRS & Alliance Islamic Bank Berhad & NUABBCI & The Bank of Nova Scotia Berhad \\
\hline NKYOIFRS & AmIslamic Bank Berhad & PUBLICBI & The Royal Bank of Scotland Berhad \\
\hline NOCIFRC & Bank Islam Malaysia Berhad & & \\
\hline NRICAUC & $\begin{array}{l}\text { Bank Muamalat Malaysia } \\
\text { Berhad }\end{array}$ & & \\
\hline NSCOTCON & CIMB Islamic Bank Berhad & & \\
\hline NUNOIFRC & $\begin{array}{l}\text { Hong Leong Islamic Bank } \\
\text { Berhad }\end{array}$ & & \\
\hline SCBBIFRS & Maybank Islamic Berhad & & \\
\hline SUMMAL & Public Islamic Bank Berhad & & \\
\hline TCMB & RHB Islamic Bank Berhad & & \\
\hline
\end{tabular}

\section{References}

Ariss, R. T. (2010). Competitive conditions in Islamic and conventional banking: A global perspective. Review of Financial Economics, 19(3), 101-108. doi:10.1016/j.rfe.2010.03.002.

Athanasoglou, P. P., Brissimis, S. N., \& Delis, M. D. (2008). Bank-specific, industry-specific and macroeconomic determinants of bank profitability. Journal of International Financial Markets, Institutions and Money, 18(2), 121-136. doi:10.1016/j.intfin.2006.07.001.

Azad, M. A. K. (2015). Efficiency of commercial banks in Bangladesh. Actual Problems of Economics/ Aktual'ni Problemi Ekonomiki, 166(4), 356-362. 
Barros, C. P., \& Wanke, P. (2014). Insurance companies in Mozambique: A two-stage DEA and neural networks on efficiency and capacity slacks. Applied Economics, 46(29), 3591-3600. doi:10.1080/ 00036846.2014 .934436$.

Battese, G. E., \& Rao, D. P. (2002). Technology gap, efficiency, and a stochastic metafrontier function. International Journal of Business and Economics, 1(2), 87-93.

Battese, G. E., Rao, D. P., \& O’Donnell, C. J. (2004). A metafrontier production function for estimation of technical efficiencies and technology gaps for firms operating under different technologies. Journal of Productivity Analysis, 21(1), 91-103. doi:10.1023/B:PROD.0000012454.06094.29.

Beck, T., Demirgüç-Kunt, A., \& Merrouche, O. (2013). Islamic vs. conventional banking: Business model, efficiency and stability. Journal of Banking \& Finance, 37(2), 433-447. doi:10.1016/j. jbankfin.2012.09.016.

Benston, G. J. (1965). Branch banking and economies of scale. The Journal of Finance, 20(2), 312-331. doi:10.1111/j.1540-6261.1965.tb00212.x.

Berger, A. N., DeYoung, R., Genay, H., \& Udell, G. F. (2000). Globalization of financial institutions: Evidence from cross-border banking performance. Brookings-Wharton Papers on Financial Services, 20(1), 23-120. doi:10.1353/pfs.2000.0001.

Berger, A. N., \& Humphrey, D. B. (1997). Efficiency of financial institutions: International survey and directions for future research. European Journal of Operational Research, 98(2), 175-212. doi:10. 1016/S0377-2217(96)00342-6.

Bonanno, G. (2015). ICT and R\&D as inputs or efficiency determinants? Analysing Italian manufacturing firms (2007-2009). [journal article]. Eurasian Business Review,. doi:10.1007/s40821-015-0035-z.

Boyd, J. H., Levine, R., \& Smith, B. D. (2001). The impact of inflation on financial sector performance. Journal of Monetary Economics, 47(2), 221-248. doi:10.1016/S0304-3932(01)00049-6.

Caves, D., Christensen, L., \& Diewert, W. (1982). The economic theory of index numbers and the measurement of input, output, and productivity. Econometrica, 6, 1393-1414. doi:10.2307/1913388.

Charnes, A., Cooper, W., Lewin, A. Y., \& Seiford, L. M. (1997). Data envelopment analysis theory, methodology and applications. Journal of the Operational Research Society, 48(3), 332-333.

Charnes, A., Cooper, W., \& Rhodes, E. (1978). Measuring the efficiency of decision making units. European Journal of Operational Research, 2(6), 429-444. doi:10.1016/0377-2217(78)90138-8.

Chen, K.-H., \& Yang, H.-Y. (2011). A cross-country comparison of productivity growth using the generalised metafrontier Malmquist productivity index: With application to banking industries in Taiwan and China. Journal of Productivity Analysis, 35(3), 197-212. doi:10.1007/s11123-0100198-7.

Cook, M. (2009). Banking reform in Southeast Asia: The region's decisive decade. Oxon: Routledge.

Cook, D., Kieschnick, R., \& McCullogh, B. (2000). Specification Errors in Studies of the Composition of Corporate Financing, University of Mississippi/University of Texas-Dallas. Drexel University, Working Paper.

Cooper, W., Seiford, L., \& Tone, K. (2006). Introduction to data envelopment analysis and its uses: With DEA-solver software and references. US: Springer Science \& Business Media.

Dietrich, A., \& Wanzenried, G. (2014). The determinants of commercial banking profitability in low-, middle-, and high-income countries. The Quarterly Review of Economics and Finance, 54(3), 337-354. doi:10.1016/j.qref.2014.03.001.

Fare, R., Grosskopf, S., Norris, M., \& Zhang, Z. (1994). Productivity growth, technical progress and efficiency changes in industrial countries. American Economic Review, 84, 66-83.

Farrell, M. J. (1957). The measurement of productive efficiency. Journal of the Royal Statistical Society. Series A, 120(30), 253-290.

Fethi, M. D., \& Pasiouras, F. (2010). Assessing bank efficiency and performance with operational research and artificial intelligence techniques: A survey. European Journal of Operational Research, 204(2), 189-198. doi:10.1016/j.ejor.2009.08.003.

Gardener, E., Molyneux, P., \& Hoai, N. L. (2011). Determinants of efficiency in South East Asian banking. [Article]. Service Industries Journal, 31(16), 2693-2719. doi:10.1080/02642069.2010. 512659.

Hayami, Y. (1969). Sources of agricultural productivity gap among selected countries. American Journal of Agricultural Economics, 51(3), 564-575.

Hoff, A. (2007). Second stage DEA: Comparison of approaches for modelling the DEA score. European Journal of Operational Research, 181(1), 425-435. doi:10.1016/j.ejor.2006.05.019.

Jeon, Y., \& Miller, S. M. (2005). Performance of domestic and foreign banks: The case of Korea and the Asian financial crisis. Global Economic Review, 34(2), 145-165. doi:10.1080/12265080500117491. 
Kamarudin, F., Nordin, B. A. A., Muhammad, J., \& Hamid, M. A. A. (2014). Cost, revenue and profit efficiency of Islamic and conventional banking sector: Empirical evidence from Gulf Cooperative Council countries. Global Business Review, 15(1), 1-24.

Lensink, R., Meesters, A., \& Naaborg, I. (2008). Bank efficiency and foreign ownership: Do good institutions matter? Journal of Banking \& Finance, 32(5), 834-844. doi:10.1016/j.jbankfin.2007.06.001.

Oh, D.-H., \& Lee, J.-D. (2010). A metafrontier approach for measuring Malmquist productivity index. [Article]. Empirical Economics, 38(1), 47-64. doi:10.1007/s00181-009-0255-0.

Papke, L. E., \& Wooldridge, J. (1993). Econometric methods for fractional response variables with an application to 401 ( $k$ ) plan participation rates. National Bureau of Economic Research Cambridge, MA, USA.

Paradi, J. C., \& Zhu, H. Y. (2013). A survey on bank branch efficiency and performance research with data envelopment analysis. Omega-International Journal of Management Science, 41(1), 61-79. doi:10.1016/j.omega.2011.08.010.

Pastor, J. T., \& Lovell, C. A. K. (2005). A global Malmquist productivity index. Economics Letters, 88(2), 266-271. doi:10.1016/j.econlet.2005.02.013.

Perry, P. (1992). Do banks gain or lose from inflation. Journal of Retail Banking, 14(2), 25-30.

Rosman, R., Wahab, N. A., \& Zainol, Z. (2014). Efficiency of Islamic banks during the financial crisis: An analysis of Middle Eastern and Asian countries. Pacific-Basin Finance Journal, 28, 76-90. doi:10.1016/j.pacfin.2013.11.001.

Sealey, C. W., \& Lindley, J. T. (1977). Inputs, outputs, and a theory of production and cost at depository financial institutions. The Journal of Finance, 32(4), 1251-1266. doi:10.1111/j.1540-6261.1977. tb03324.x.

Simar, L., \& Wilson, P. W. (2007). Estimation and inference in two-stage, semi-parametric models of production processes. Journal of Econometrics, 136(1), 31-64. doi:10.1016/j.jeconom.2005.07.009.

Sufian, F. (2011). Banks total factor productivity change in a developing economy: Does ownership and origins matter? Journal of Asian Economics, 22(1), 84-98. doi:10.1016/j.asieco.2010.07.007.

Sufian, F., \& Habibullah, M. S. (2010). Bank-specific, industry-specific and macroeconomic determinants of bank efficiency empirical evidence from the Thai banking sector. Margin: The Journal of Applied Economic Research, 4(4), 427-461.

Sufian, F., \& Kamarudin, F. (2015). Determinants of revenue efficiency of Islamic banks: Empirical evidence from the Southeast Asian countries. International Journal of Islamic and Middle Eastern Finance and Management, 8(1), 1-30. doi:10.1108/IMEFM-12-2012-0114.

Sufian, F., Kamarudin, F., \& Noor, N. H. H. M. (2014). Revenue efficiency and returns to scale in Islamic banks: Empirical evidence from Malaysia. Journal of Economic Cooperation and Development, 35(1), 47-80.

Sufian, F., Mohamad, A., \& Muhamed-Zulkhibri, A. M. (2008). The efficiency of Islamic Banks: Empirical evidence from the MENA and Asian countries Islamic banking sectors. The Middle East Business and Economic Review, 20(1), 1-19. doi:10.1108/17538390910965149.

Wagner, J. M., \& Shimshak, D. G. (2007). Stepwise selection of variables in data envelopment analysis: Procedures and managerial perspectives. European Journal of Operational Research, 180(1), 57-67. doi:10.1016/j.ejor.2006.02.048.

Wang, X. P. (2006). Banking efficiency in China: Application of DEA and Tobit analysis. Proceedings of the 2006 International Conference on Management Science and Engineering, 557-561, 1478.

Wanke, P., Azad, M. A. K., \& Barros, C. P. (2016a). Predicting efficiency in Malaysian Islamic banks: A two-stage TOPSIS and neural networks approach. Research in International Business and Finance, 36, 485-498. doi:10.1016/j.ribaf.2015.10.002.

Wanke, P., Azad, M. A. K., Barros, C. P., \& Hadi-Vencheh, A. (2015). Predicting performance in ASEAN banks: An integrated fuzzy MCDM-neural network approach. Expert Systems,. doi:10. 1111/exsy.12144.

Wanke, P., Azad, M. A. K., Barros, C. P., et al. (2016b). Financial distress and the Malaysian dual baking system: A dynamic slacks approach. Journal of Banking \& Finance, 66, 1-18. doi:10.1016/j. jbankfin.2016.01.006.

Wanke, P., \& Barros, C. P. (2016). Efficiency drivers in Brazilian insurance: A two-stage DEA meta frontier-data mining approach. Economic Modelling, 53, 8-22. doi:10.1016/j.econmod.2015.11.005.

Williams, B. (2003). Domestic and international determinants of bank profits: Foreign banks in Australia. Journal of Banking \& Finance, 27(6), 1185-1210. doi:10.1016/S0378-4266(02)00251-0.

Wilson, P. W. (2008). FEAR: A software package for frontier efficiency analysis with R. Socio-Economic Planning Sciences, 42(4), 247-254. doi:10.1016/j.seps.2007.02.001. 